\title{
Peculiarities of ecological tourism and its region importance in socio- economic life
}

\author{
Islomova R.A A Idrisova Sh. $^{2}$ \\ ${ }^{1,2}$ Navoi State Mining Institute, Uzbekistan
}

\begin{abstract}
This paper makes analyses of the Peculiarities of ecological tourism and its regionimportance in socio-economic life. On this way, research has been pinpointed in the various ways of the tourism and its regional importance from socio and economic perspective. It makes outcome and shortcomings as the whole.
\end{abstract}

Keywords:Peculiarities, econological tourism, regional importance, socio-economic life

\section{INTRODUCTION}

Resolution No. PK-3514 "On measures to ensure the rapid development of domestic tourism", Resolution No. PK4095 of January 5, 2019 "On additional measures for the accelerated development of tourism in the Republic of Uzbekistan." Dozens of decrees and decisions were also adopted on free economic zones. Currently, there are free economic zones in 14 regions of the country. All of the above regulations serve to some extent in the implementation of the objectives of improving the organizational and economic mechanisms for the development of ecotourism, especially in free economic zones.

Ecotourism has its own characteristics due to the fact that it is directly related to the environment compared to other types of tourism. Along with the positive aspects of eco-tourism, there are also negative aspects. This is also the case in Navoi region. They can be described as follows (Figure 1).

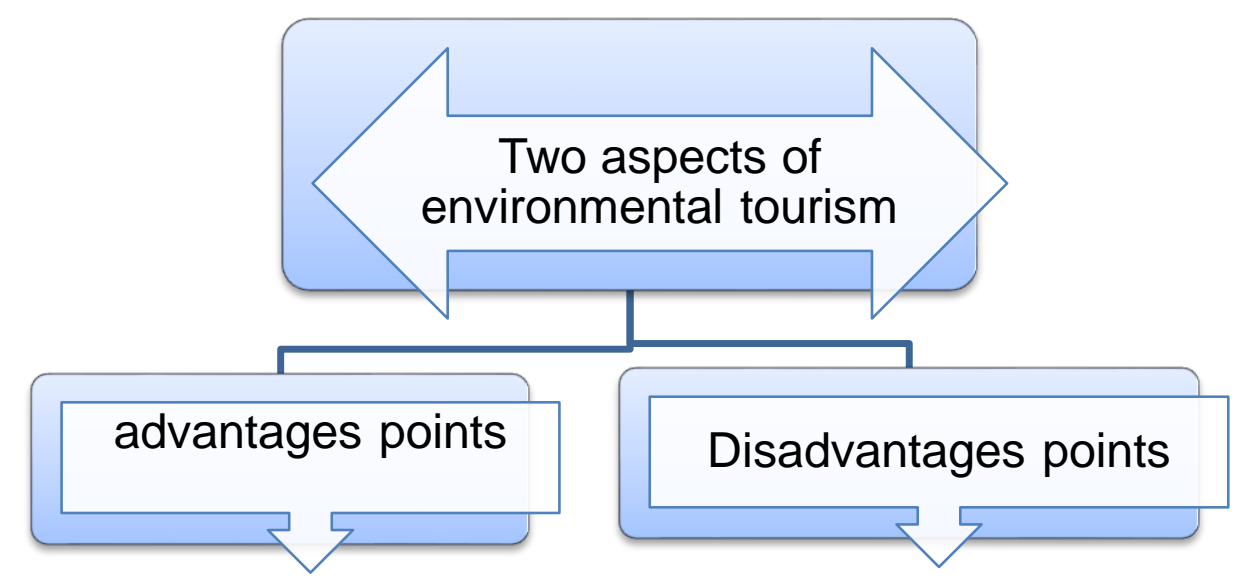

Figure 1. Different aspects of eco-tourism

The positive aspects of the development of eco-tourism for the region, especially if it is achieved at the international level, will create the following benefits:

- Increases foreign exchange earnings to the regional treasury;

- creates opportunities and necessity for the establishment of national parks, zopovedniks in the region;

- leads to the reproduction of artificial forests in the vacant lands of the region, using internal resources;

- Ensures the improvement of water bodies and riverbanks;

- There will be additional financial opportunities for environmental protection in the region;

- creates the need to travel to deserts and steppes, and their inclusion in the ecotourism object creates the opportunity to bring additional income;

- The development of this tourism requires, accordingly, the formation and development of infrastructure, resulting in the emergence of many new businesses;

- The development of ecotourism will help solve the problem of employment by creating new jobs in the region. 


\section{MAIN ANALYSES}

These positive developments are related to the further development of the socio-economic life of the region and the provision of comfortable recreation for tourists. However, along with the positive aspects of eco-tourism, there are also negative aspects that should be taken into account in its organization. These include:

- The re-creation of national parks and similar tourist facilities in the region can certainly lead to the reduction of pastures and, accordingly, the reduction of livestock in the region;

- Due to the increase in the number of tourists, the organization of bathing in running water can lead to its pollution, and the use of many vehicles, as well as air pollution;

- Due to the fact that one of the directions of eco-tourism is related to hunting, in exchange for various shootings, the escape of wild animals, birds, fish leads to a decrease;

- With the emergence of recreational facilities in ecotourism facilities, the increase in the number of facilities associated with the organization of their recreation may also lead to excessive noise in the area;

- Tourists may also be at risk of extinction as a result of exposure to various food and other wastes, various diseases of local wildlife and birds due to their fermentation and spoilage;

- As a result of the negative impact on the fauna and flora of the area developed for the organization of ecotourism, many rare plants become extinct, which can lead to disruption of the natural balance as a result of non-growth and migration of several wild animals;

- It can also lead to the early felling of several trees in the area due to the burning of tourists.

It is also clear that the development of eco-tourism should be done not only from a commercial point of view, but also from the point of view of environmental protection. Admittedly, environmental protection measures are much cheaper than repairing a damaged environment. The wound of nature is a wound that is difficult to heal. Because once nature has created an environment that adapts to itself, it is difficult for man to restore it to its original state if it has been destroyed. Therefore, the need to combine the development of ecotourism with environmental protection is one of the peculiarities of ecotourism. If the negative effects of eco-tourism are not addressed, large losses can be incurred to achieve a certain amount of commercial goals. It is therefore necessary to develop and achieve ways to overcome the negative consequences. These pathways are also divided into two groups (Figure 2).

Direct ways to eliminate the negative impact of eco-tourism on the environment include:

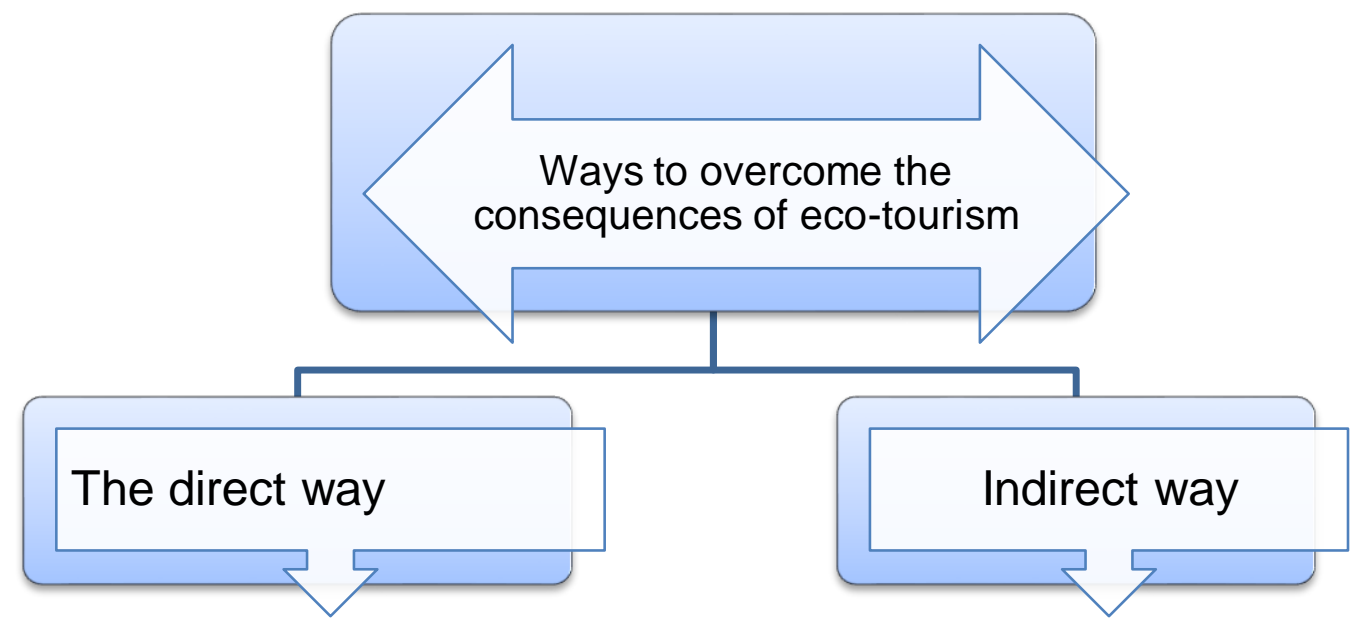

Figure 2. Ways to overcome the negative effects of eco-tourism on the environment.

- on tourist routes for eco-tourism should be developed and strictly adhered to in an environmentally friendly manner;

- Due to the need to organize the flow of people to ecological tourists, depending on the capabilities of the ecological facility, it is necessary to ensure that the ecological site does not overcrowd;

- if there is a specially protected area or animals at the location of the ecological tourist facility, they should be separated from people with special devices;

Indirect ways to mitigate the negative effects of eco-tourism on the environment include:

- Encourage and require environmental tourists to take measures not to damage the environment as a result of raising their environmental awareness;

- to include in the words of the guides the need to improve the relations of tourists with the local population, to 
have a good relationship with the flora and fauna of the area;

- to take measures to make every tourist aware of the need to preserve rare animals and rare plants that are difficult to restore.

In order to develop a conceptual framework and directions for the development of eco-tourism, it is necessary to identify its specific features. However, in the literature on tourism, eco-tourism, which is an integral part of it, there is almost no information about its characteristics in relation to general tourism. Only M. Hoshimov's monograph says a few words about it. According to him, the peculiarities of ecotourism are:

- The local population participates in the socio-economic development of their territories;

- the majority of naturalness among tourist facilities;

- use of independent nature;

- low power consumption;

- Ecological knowledge of tourists.

There are a number of shortcomings in this feature. In particular, the issue of unexpected encounters with wildlife and wildlife during the tourist trip was not reflected. Also, ecotourism is carried out mainly in rural and mountainous areas, ensuring the harmony of nature and human relations is not included in this list. In addition, as an ecotourism object, mainly nature, ethnographic culture and customs of the local population, their way of life are also characteristic features of ecotourism. But this issue has also been overlooked.

In contrast to these views, the Russian scientist VV Khrabovchenko also cites 5 features. These include:

- The tourist explores the environment on any ecotourism trip;

- nature is the main factor during the trip;

- Revenues from ecotourism are mainly spent on environmental protection;

- Ecotourist is personally involved in the conservation and restoration of wildlife;

- Ecotour - is a trip in which all the activities are carried out in an "environmentally friendly" state.

This feature takes into account almost all the features of ecotourism. However, the participation of local people in the socio-economic development of their regions through the development of eco-tourism is not taken into account. Also, low energy consumption in ecotourism is not reflected in this feature. Also, the issue of unexpected wildlife, conflict with wildlife, ecotourism is carried out mainly in rural and mountainous areas, ensuring the harmony of nature and human relations, mainly nature as an ecotourism object, ethnographic culture and customs of the local population, their way of life. features. However, these issues are not reflected in this list. Due to this, the nature of ecotourism requires improvement.

In our opinion, these specific features of eco-tourism do not have the ability to fully disclose its content. This is because these features do not reflect all the aspects of this concept that we have justified and recommended. With this in mind, we found it expedient to bring our views on the subject into a single system. (Table 3 ).

Table 1.4

Features of ecotourism in relation to general tourism ${ }^{1}$

\begin{tabular}{|l|l|}
\hline The situation in general tourism & Peculiarities of eco-tourism \\
\hline $\begin{array}{l}\text { 1. All tourist facilities are involved in the tourist process } \\
\text { in general tourism }\end{array}$ & $\begin{array}{l}\text { Only eco-tourism facilities are involved in the tourist } \\
\text { process in eco-tourism }\end{array}$ \\
\hline $\begin{array}{l}\text { 2. Tourist facilities (resources) are mostly built by } \\
\text { people }\end{array}$ & $\begin{array}{l}\text { Tourist facilities (resources) are mainly a blessing of } \\
\text { nature. }\end{array}$ \\
\hline $\begin{array}{l}\text { 3. In general tourism, the tourist is in the cities, places } \\
\text { of historical monuments, cultural heritage. }\end{array}$ & $\begin{array}{l}\text { In eco-tourism, the tourist is in the bosom of nature and, } \\
\text { while enjoying nature, explores it. }\end{array}$ \\
\hline $\begin{array}{l}\text { 4. During the trip, the tourist will be able to see the } \\
\text { objects included in the planned tourist route. }\end{array}$ & $\begin{array}{l}\text { During the trip, the tourist encounters unexpected } \\
\text { wildlife, fauna, and expands his imagination about } \\
\text { nature. }\end{array}$ \\
\hline $\begin{array}{l}\text { 5. In general tourism, the tourist is in all places included } \\
\text { in the tourist route (urban, rural, desert, mountainous } \\
\text { areas). }\end{array}$ & $\begin{array}{l}\text { Ecotourism is mainly carried out in rural and } \\
\text { mountainous areas, ensuring the harmony of nature and } \\
\text { human relations. }\end{array}$ \\
\hline $\begin{array}{l}\text { 6. In general tourism as a tourist object participates all } \\
\text { tourist resources of the region, the general way of life, } \\
\text { customs of the local population. }\end{array}$ & $\begin{array}{l}\text { The main objects of ecological tourism are nature, } \\
\text { ethnographic culture and customs of the local } \\
\text { population, their way of life. }\end{array}$ \\
\hline 7. In general tourism, tourists may have no relationship & Through ecotourism, nature protection is provided \\
\hline
\end{tabular}

\footnotetext{
${ }^{1}$ Author construction
} 


\begin{tabular}{|l|l|}
\hline with nature and no impact on nature. & $\begin{array}{l}\text { directly and indirectly, and all its components are } \\
\text { preserved and improved. }\end{array}$ \\
\hline $\begin{array}{l}\text { 8. In general tourism, the living standards of urban and } \\
\text { rural population will be improved and the local } \\
\text { economy will develop. }\end{array}$ & $\begin{array}{l}\text { Through eco-tourism, the living standards of the rural } \\
\text { population will be improved and the local economy will } \\
\text { develop. }\end{array}$ \\
\hline $\begin{array}{l}\text { 9. The main part of the total income (income) from } \\
\text { tourism goes to the improvement of the activities of } \\
\text { tourism firms. }\end{array}$ & $\begin{array}{l}\text { While part of the proceeds (income) from eco-tourism } \\
\text { is spent on tourism firms, the main part is used for } \\
\text { environmental protection. }\end{array}$ \\
\hline $\begin{array}{l}\text { 10. Low risk in general tourism, as this situation is } \\
\text { ensured on pre-planned tourist routes. }\end{array}$ & $\begin{array}{l}\text { There are risks in eco-tourism, such as the occurrence } \\
\text { of various events on pre-planned tourist routes, } \\
\text { encounters with wild animals, natural disasters such as } \\
\text { rain, lightning. }\end{array}$ \\
\hline $\begin{array}{l}\text { 11. Existence of cases when general tourism does not } \\
\text { always require special skills from tourists. }\end{array}$ & $\begin{array}{l}\text { In eco-tourism, tourists are sometimes required to have } \\
\text { special skills. Climbing from him to conquer mountain } \\
\text { peaks, a special skill suitable for cave tourism, the } \\
\text { availability of appropriate experience for skiing in the } \\
\text { mountains. }\end{array}$ \\
\hline
\end{tabular}

First, in general tourism, all tourist facilities participate in the tourist process, while in eco-tourism, only ecological tourist facilities participate in this process. Thus, in terms of scale, eco-tourism is considered to be much smaller as an integral part of general tourism.

Second, in general tourism, tourist facilities (resources) are mostly various monuments, monuments and structures built by humans, while in eco-tourism, tourist facilities (resources) are mainly a gift of nature. This aspect of it is characterized by the relative cheapness of eco-tourism.

Third, while in general tourism, tourists travel to cities, historical monuments, cultural heritage sites, in ecotourism, the tourist is in the bosom of nature and explores it while enjoying nature. Nowadays, much of nature is unprotected. Therefore, it can be visited by many wild, ie unorganized tourists. In such cases, the issue of nature and environmental protection is in a somewhat dangerous state.

Fourth, in general tourism, the tourist will be able to see the objects included in the planned tourist route during the trip, while in eco-tourism, the tourist will encounter unexpected wild flora and fauna during the trip. Tourists can experience a variety of adventures, bizarre events, surprises and coincidences during eco-tourism.

Fifth, in general tourism, the tourist is in the places included in the tourist route (such as city, village, desert, mountain) according to the plan. In eco-tourism, tourists travel mainly in nature. This ensures the harmony of nature and human relations.

Sixth, all tourism resources in the region, the general lifestyle and customs of the local population are considered as tourist objects in general tourism, while nature, ethnographic culture and customs of the local population and their way of life are considered as tourist objects in ecotourism. Because the object of ecotourism is the nature of nature and the "nature" of people. The nature of a population is reflected in its mentality, customs, and way of life.

Seventh, in general tourism, the relationship of tourists with nature and their impact on nature may or may not be noticeable, but in ecotourism, through the implementation of this process, nature protection is provided directly and indirectly and all its components are preserved and improved. Because the ecological tourist route is designed and implemented in a way that does not harm nature. Part of the proceeds will be spent on the protection and restoration of the environment, namely these ecological tourist facilities.

Eighth, in general tourism, the living standards of the urban and rural population will be restored and the local economy will develop. In eco-tourism, on the other hand, the living standards of the rural population will improve and the local economy associated with rural areas will develop. Because this area will provide cash (currency) income, employment will increase and eventually their living standards will rise.

Ninth, while the bulk of total tourism revenue (revenue) goes to rehabilitating tourism firms, the bulk of ecotourism revenue comes from rehabilitating tourism firms and, as noted above, to protect the environment. Another important aspect of eco-tourism is that it creates more opportunities to restore human health.

Tenth, the low risk in general tourism, because in pre-planned tourist routes this situation is provided, the presence of risk in eco-tourism, because the occurrence of various events on pre-planned tourist routes, encounters with wild animals, natural disasters such as rain, lightning tribe

Eleventh, while general tourism does not always require special skills from tourists, eco-tourism may require special skills from tourists in some cases. Examples of mountaineering require mountaineering, special skills for cave Volume 3, Issue X, October $2020 \mid 325$ 
tourism, and the appropriate experience to ski in the mountains.

\section{CONCLUSION}

To determine the place of eco-tourism in the economy and social life of Navoi region, it is enough to compare the growth rate of gross regional product (GRP), population growth and the number of eco-tourists.

\section{REFERENCES}

1. Resolution of the Cabinet of Ministers of the Republic of Uzbekistan dated August 15, 2014 No 234 "On measures to further improve the system of retraining and advanced training of public educators." (Appendix 1: Regulations on retraining and advanced training of public educators.) - Tashkent, "Development of education", №4.

2. Resolution of the Cabinet of Ministers of the Republic of Uzbekistan dated March 25, 2015 No 67 "On additional measures to improve the skills and professionalism of teachers of foreign languages in secondary schools.

3. State requirements to the content and quality of education in the system of retraining and advanced training of public educators. // Approved by the order of the Ministry of Public Education of the Republic of Uzbekistan dated July 25, 2012 No 227 and registered in the State Agency UzStandard on February 1, 2013 under the registration number UzSS 2767: 2013.

4. Barbera, E., Garcia, I. and Fuertes-Alpiste, M. (2017), "A co-design process microanalysis: Stages and facilitators of an inquiry-based and technology-enhanced learning scenario", The International Review of Research in Open and Distributed Learning, Vol. 18, No. 6, doi: 10.19173/irrodl.v18i6.2805

5. Carretero, S., Vuorikari, R. and Punie, Y. (2017), DigComp 2.1: The Digital Competence Framework for Citizens with eight proficiency levels and examples of use, EUR 28558 EN. doi:10.2760/38842.

6. Cheung, G., Wan, K. and Chan, K. (2018), "Efficient use of clickers: A mixed-method inquiry with university teachers", Education Sciences, Vol. 8, No. 31, doi:10.3390/educsci8010031

7. Chiao, H.-M., Chen, Y.-L. and Huang, W.-H. (2018), "Examining the usability of an online virtual tour-guiding platform for cultural tourism education”, Journal of Hospitality, Leisure, Sport \& Tourism Education, Vol. 23, pp. 29-38, doi: 10.1016/j.jhlste.2018.05.002

8. Framke, W. (2002), "The Destination as a Concept: A Discussion of the Business-related Perspective versus the Socio-cultural Approach in Tourism Theory”, Scandinavian Journal of Hospitality and Tourism, Vol. 2, No. 2, pp. 92-108, doi:10.1080/15022250.2014.886100

9. Law, R., Buhalis, D. and Cobanoglu, C. (2014), "Progress on information and communication technologies in hospitality and tourism", International Journal of Contemporary Hospitality Management, Vol. 26, No. 5, pp.727-750, doi:10.1108/IJCHM-08-2013-0367

10. Lin, J. and Cantoni, L. (2018), "Decision, implementation, and confirmation: Experiences of instructors behind tourism and hospitality MOOCs", International Review of Research in Open and Distributed Learning, Vol. 19, No. 1, pp. 275-293.

11. Patiar, A., Ma, E., Kensbock, S. and Cox, R. (2017), "Students' perceptions of quality and satisfaction with virtual field trips of hotels", Journal of Hospitality and Tourism Management, Vol. 31, pp. 134-141, doi:10.1016/j.jhtm.2016.11.003

12. Schaffer, V. (2017), "Enhancing learning to diverse cohorts via immersive visualization", Journal of Hospitality, Leisure, Sport \& Tourism Education, Vol. 21, pp. 46-54, doi: 10.1016/j.jhlste.2017.07.001

13. Schott, C. (2017), "Virtual fieldtrips and climate change education for tourism students", Journal of Hospitality, Leisure, Sport \& Tourism Education, Vol. 21, pp. 13-22, doi: 10.1016/j.jhlste.2017.05.002

14. World Economic Forum (2017), Digital Transformation Initiative: Aviation, Travel and Tourism Industry, Geneva:Switzerland. URL: http://reports.weforum.org/digital-transformation/wpcontent/blogs.dir/94/mp/files/pages/files/wef-dti-aviation-travel-and-tourism-white-paper.pdf

15. Xiao, C., Qiu, H. and Cheng, S.M. (2019), "Challenges and opportunities for effective assessments within a quality assurance framework for MOOCs", Journal of Hospitality, Leisure, Sport \& Tourism Education, Vol. 24, pp. 1-16, doi: 10.1016/j.jhlste.2018.10.005 